\title{
Determinants of Poverty Status among Crop and Fish Farmers in Southern Nigeria
}

\author{
I. O. Ettah ${ }^{1}$, E. Agbachom Emmanuel ${ }^{1}$, Ajigo Ikutal $^{2}$ \\ and Godwin Michael $\mathrm{Ubi}^{3^{*}}$
}

${ }^{1}$ Department of Agricultural Economics, Faculty of Agriculture, Forestry and Wildlife Resources Management, University of Calabar, P.M.B. 1115, Calabar, Nigeria.

${ }^{2}$ Department of Vocational and Special Education, Faculty of Education, University of Calabar, P.M.B 1115, Calabar, Nigeria.

${ }^{3}$ Department of Genetics and Biotechnology, Faculty of Biological Sciences, University of Calabar,

P.M.B. 1115, Calabar, Nigeria.

\section{Authors' contributions}

This work was carried out in collaboration among all authors. Author IOE designed the study. Authors IOE and GMU performed the statistical analysis. Authors IOE, EAE and Al wrote the protocol. Authors IOE and GMU wrote the first draft of the manuscript. Authors IOE and GMU managed the analyses of the study. Authors Al and EAE managed the literature searches. All authors read and approved the final manuscript.

Article Information

DOI: $10.9734 / A R R B / 2020 / v 35 i 330203$ Editor(s):

(1) Dr. Viduranga Y. Waisundara, Australian College of Business and Technology, Sri Lanka. Reviewers:

(1) Emmanuel Dodzi Kutor Havi, Methodist University College, Ghana. (2) Imam Mukhlis, Universitas Negeri Malang, Indonesia. Complete Peer review History: http://www.sdiarticle4.com/review-history/54506

Original Research Article

Received 04 December 2019

Accepted 09 February 2020

Published 18 May 2020

\begin{abstract}
The research study was carried out to determine the poverty status and their determinants among crop and fish farmers in Itu Local Government Area of Akwa Ibom State, Nigeria. A two-stage sampling technique was adopted to select crop farmers and fish farmers' households in the study area. The data used for this study were obtained from primary sources. Data were obtained through validated structured questionnaires. The determinant of poverty among crop farmers and fish farmers was analyzed using logistic regression, while poverty indicators were analyzed using the three indicators of poverty as highlighted in the Foster, Greer and Thorbecke (FGT) model. Result of analysis on the incidence of poverty shows that about $52.5 \%$ of crop farmers and $62.5 \%$ of fish farmers in the area had their per capita income less than the poverty line income. The result also
\end{abstract}


showed that poverty depths of 0.342 for crop farmers and 0.309 for fish farmers in the area. Similarly, the severity of the poverty index was 0.252 for crop farming households and 0.221 for fish farmers' headed households. On the determinants of crop farmers, gender, age, marital status education, farm size and membership of association were all found to be positive and significant determinants, while education, credit, farm income and experience were the positive and significant determinant of poverty among fish farmers in the area. The following are recommended: credit delivery mechanism which is without or with very minimal stringent conditions (such as the provision of collateral) targeting the poor crop farming and fishing households should be implemented and improved crop farmers/fishermen access to technological information.

Keywords: Poverty; crop farmers; fisher folks; indicators; farm business.

\section{INTRODUCTION}

The United Nations Department of Economic and Social Affairs [1] report on common country assessment stated that Nigeria is one of the poorest and most unequal countries in the world, with over 76 million or 64 per cent of her population living below poverty line. Poverty and hunger have remained high in rural areas, remote communities and among female-headed households and these cut across the six geopolitical zones of the country. Poverty is seen as a situation of low income and/or low consumption. People are considered poor when their measured standard of living is below a minimum acceptable level of poverty known as poverty line [2]. On a global dimension as reported by FAO [3] a look at the extent of food insecurity beyond severe levels and hunger reveals that an additional 17.2 percent of the world population, or 1.3 billion people, have experienced food insecurity at moderate levels, meaning they did not have regular access to nutritious and sufficient food.

According to Olutosin et al. [4] poverty is strongly associated with hunger in Nigeria. The authors contended that the National Social Investment Programmes are major tools for reducing hunger in Nigeria but that country is not making significant progress towards ending hunger soonest. Many developing countries, especially African countries, are faced with extreme hunger often caused or compounded by bad governance, conflicts and climate change. Efforts towards eradicating poverty and achieving Millennium Development Goals (MDGs) are being carried out by Governments, NonGovernmental Organizations (NGOs), International organizations, and private institutions in Akwa Ibom State and Nigeria and around the world. The organization aims to reduce by $50 \%$ the number of people who suffer from poverty [5]. In Akwa Ibom State, Nigeria government and non-governmental organizations at national and international levels have been doing a lot towards poverty reduction, but their concentration is mostly in the urban centres.

Poverty has generated a lot of interest in recent times and poverty reduction strategies are increasingly being accorded centrality in the development planning process. According to several authors [6-8], more than $60 \%$ of the rural population who are mostly farmers in Sub Saharan Africa live below the poverty line and do not have sufficient access to social amenities and infrastructures. As noted by several authors $[9,10]$, the UN Human Poverty Index, in 1999, placed Nigeria among the 25 poorest nations in the world. To substantiate this fact, the UNDP report [11] asserted that, about 68.7 million Nigerians were poor in 2004; while it rose to 112.7 million in 2010 representing $69 \%$ of the population. Issues related to poverty and income inequality are mostly reported as a rural phenomenon and more prevalent among farming households in Nigeria [12].

However, it has been established that majority of the poor in Akwa Ibom State and elsewhere in Sub-Sahara Africa live in rural areas and depend on agriculture and fishing as their principal means of survival [13]. Therefore significant increases in agricultural productivity and fishing must be supported and achieved at the household level [14] and this can only be achieved if the factors that determined poverty status of the farm households and fishermen are empirically determined and addressed. To date farming household and fishermen level research on poverty challenges in Ikot Offiong, Itu Local Area of Akwa lbom State is limited. Mishra $[15,16]$ used regression method on cumin and black pepper to find the factor affecting their production. This study which intends to analyze and compare the poverty status and factors that 
influence the poverty status of rural farmers and fishermen in Akwa Ibom State, Nigeria used poverty index and will not only add to the topical issue of poverty but will be of immense use to policymakers. The study, therefore, sought to address the following objectives:

i. Determine the poverty status of crop farmers and fishermen in the study area;

ii Analyze the determinant of poverty among farmers and fishermen in the study area;

\section{RESEARCH METHODOLOGY}

\subsection{Description of Study Area}

The study was conducted in Ikot Offiong, Itu Local Government Area in Akwa Ibom State, South-South region of Nigeria. Ikot Offiong lies within the humid tropical rainforest zone of Nigeria with an average annual precipitation range of $2000 \mathrm{~mm}-3000 \mathrm{~mm}$, and is located between latitude $40^{\circ}$ and $20^{\circ} \mathrm{N}$ of the equator and longitude $30^{\circ}$ and $47^{\circ} \mathrm{E}$ of the meridian and has an area of about 128.32 square kilometres and a population of about 327, 033 [17]. Itu Local Government Area is bounded in the north by Odukpani and Arochukwu Local Government Area in Cross River and Abia States respectively, in the west by Ibiono-lbom and Ikono Local Government Areas, in the south by Uyo Local government Area and in the east by Uruan Local Government Area. The people of the area are predominantly crop farmers and fishermen and are Ibibio speaking group with pockets of Efik speaking people and the ljaws.

\subsection{Sampling Technique and Sample Size}

A two stage sampling technique was adopted to select crop farmer and fishermen households in the study area. The first stage involved the purposive selection of Ikot Offiong out of all the clans in Itu LGA., because of the prevalence of fishermen and proximity to watercourse and high crop activities in the area. The second stage involved the random selection of forty (40) crop farmers and fishermen each from the area to give a total sample size of eighty (80) respondents. This sample was obtained from the list of registered crop farmers and fishermen from the Department of Agriculture in the Local Government Headquarters.

\subsection{Method of Data Collection and Analysis}

The data that were used for this study was obtained from primary sources. Primary data were obtained through validated structured questionnaires and were designed based on the study objectives. Data collected were analyzed using inferential statistics; the specific method for each objective was as follows:

Objective i: The poverty status of crop farmers and fishermen in the study area was analyzed using Foster, Greer and Thorbecke (FGT) Poverty Index.

Objective ii: The determinant of poverty among farmers and fishermen in the study area was analyzed using logistic regression.

\subsection{Model Specification}

\subsubsection{Logistic regression model}

In order to identify the determinants of poverty status of crop farmers and fishermen households, a logit regression was carried out. The model was chosen because of the dichotomous dependent variables and because the technique has no restrictive distribution assumptions.

The logistic (logit) probability function is given as;

$$
P_{i}=\frac{1}{1+e^{-(\alpha+\beta X)}}=f\left(Z_{i}\right)
$$

Where $\mathrm{Pi}$ is the probability that a household $\mathrm{i}(\mathrm{i}=$ $1,2 \ldots n$ ) would be poor. Index $Z_{i}$ is a random variable which predicts the probability of a household being poor or non-poor. The probability $\mathrm{Pi}$ in equation $\mathrm{i}$ is further transformed to give equation ii as follows:

$$
\mathrm{Pi}=\mathrm{e}^{\mathrm{zi}} / 1+\mathrm{e}^{\mathrm{zi}}
$$

Therefore for the ith observation, a household would be

$$
\frac{P_{i}}{1-P i}=Z_{i}=\beta_{0}+\beta X_{1}+\beta_{2} X_{2}+\ldots \ldots . .+\beta_{n} X_{n}+U_{i}
$$

Where,

$\mathrm{Pi}=$ the probability of a crop farmer being poor, where $Y=1$.

$1-\mathrm{Pi}=$ the probability of a crop farmer or fisher not being poor, where $Y=0$.

$\mathrm{Xi}=$ is a vector representing explanatory variables.

$\mathrm{Ui}=$ is the random error term. Explicitly, the model is specified as follows 


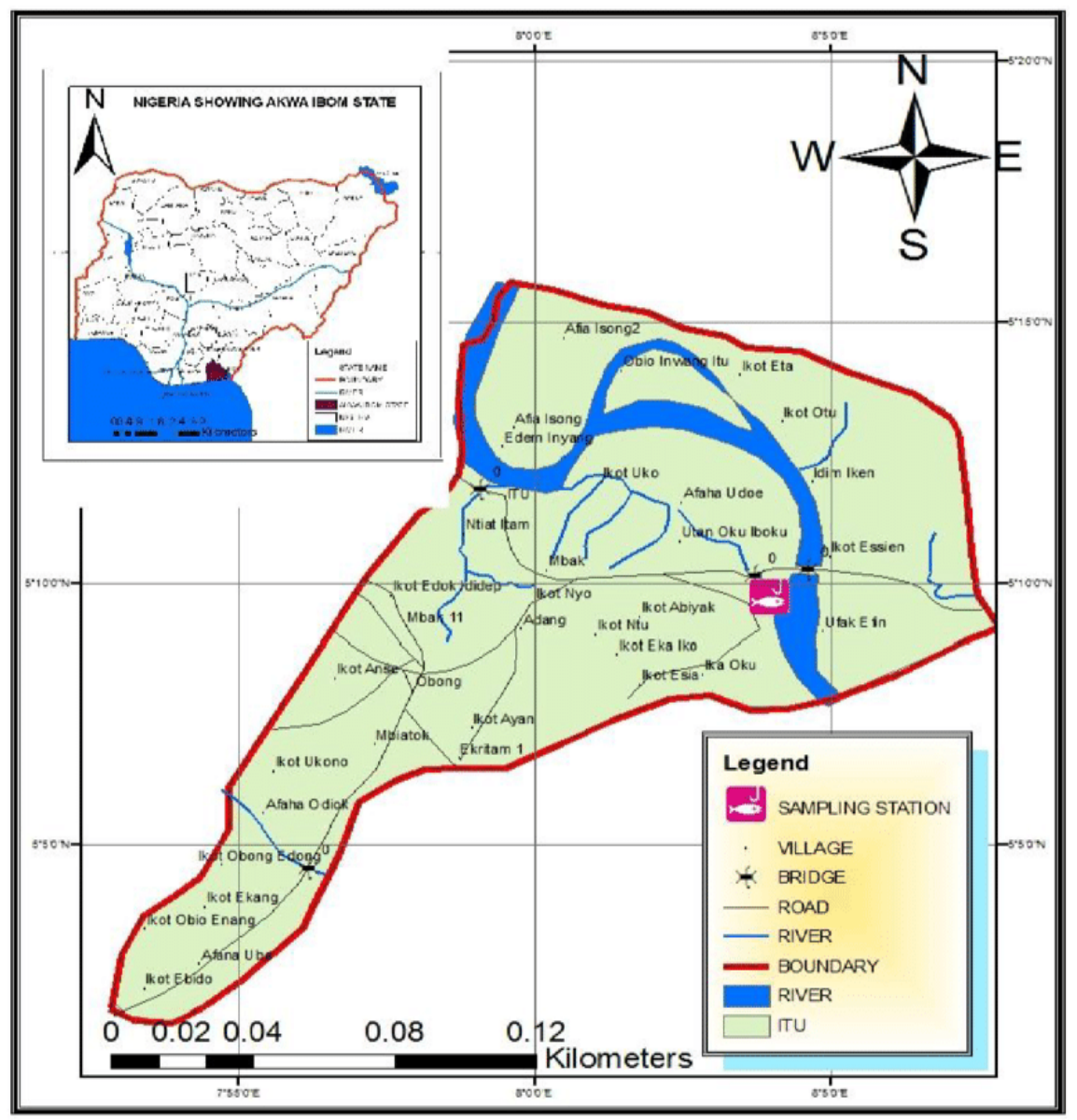

Map 1. Map of Itu L. G. A. Akwa Ibom State, Nigeria 
Model 1 for crop farmers:

$Y=\beta 0+\beta 1 X 1+\beta 2 X 2+\beta 3 X 3+\beta 4 X 4+\beta 5 X 5+\beta 6$ $X 6+\beta 7 \times 7+\beta 8 X 8+\beta 9 X 9+\beta 10 \times 10+U i$

Where:

$Y=$ Poverty status of farm households sampled

( $1=$ if poor, 0 otherwise)

$\mathrm{Xi}=$ Farm size (hectares),

$\mathrm{X}_{2}=$ Highest educational level (years of formal schooling)

$\mathrm{X}_{3}=$ Farming experience (years),

$\mathrm{X}_{4}=$ Age of household head (years),

$X_{5}=\operatorname{Sex}($ male $=1$, female $=0)$,

$\mathrm{X}_{6}=$ Household size (number)

$X_{7}=$ off farm income ( $)$,

$\mathrm{X}_{8}=$ farm income

$\mathrm{X}_{9}=$ Membership of farmer association (member

$=1$ and 0 , otherwise)

$\mathrm{X}_{10}=$ Amount of credit accessed (\#),

$\mathrm{Ui}=$ errors term

\section{Model 2: for fishermen}

$Y=\beta 0+\beta 1 X 1+\beta 2 X 2+\beta 3 X 3+\beta 4 X 4+\beta 5 X 5+\beta 6$

$X 6+\beta 7 \times 7+\beta 8 \times 8+\beta 9 \times 9+\beta 10 \times 10+U i$

Where:

$\mathrm{Y}=$ Poverty status of fishermen sampled $(1=$ if poor, 0 otherwise)

$X_{1}=$ Marital status $(D=1$ if married, 0 if otherwise)

$\mathrm{X}_{2}=$ Highest educational level (years of formal schooling)

$\mathrm{X}_{3}=$ Fishing experience (years),

$X_{4}=$ Age of household head (years),

$\mathrm{X}_{5}=\operatorname{Sex}($ male $=1$, female $=0)$,

$X_{6}=$ Household size (number)

$X_{7}=$ Non- fishing income ( $)$,

$X_{8}=$ fish farming income (\#)

$X_{9}=$ Membership of farmer association (member $=1$ and 0 , otherwise)

$\mathrm{X}_{10}=$ Amount of credit accessed for fishing activities (\#),

$\mathrm{Ui}=$ errors term

\subsubsection{Foster Greer Thorbecke (FGT) poverty indices}

The FGT measure was used to determine the level of poverty among crop farmers and fishermen (Foster Greer \& Thorbecke, 1984). The FGT poverty index is given as:

$$
P_{\alpha i}(y, z)=\frac{1}{n} \sum_{i=1}^{q}\left(\frac{z-y_{i}}{z}\right)^{\alpha}
$$

Where

$\mathrm{n}=$ Total number of rural farm households under consideration

$q=$ Number of poor rural farm households (those below the poverty line)

$Z=$ Poverty line, estimated using $\frac{2}{3}$ mean per

capita expenditure of all households

$y i=$ per capita expenditure of the $i^{\text {th }}$ household

$\alpha=$ poverty aversion parameter and takes on value $0,1,2$

$\left(\frac{z-y_{i}}{z}\right)=$ proportion shortfall in expenditure below the poverty line. Determining the poverty index, When $\alpha=0$ in FGT, the expression becomes: $P_{0}=(q)\left(\frac{1}{n}\right)=\frac{q}{n}=H$

This is called the Incidence of poverty or headcount index, which measures the proportion of the population that is poor i.e. falls below the poverty line.

When $\alpha=1$ in FGT, the expression becomes: $P_{1}=\frac{1}{2} \sum_{i=1}^{q}\left(\frac{z-y_{i}}{z}\right)$

This is called Poverty depth or Poverty gap index, which measures the extent to which individuals fall below the poverty line as a proportion of the poverty line.

When $\alpha=2$ in FGT, the expression becomes: $P_{2}=\frac{1}{n} \sum_{i=1}^{q}\left(\frac{z-y_{i}}{z}\right)^{2}$

This is called Poverty severity index measures the squares of the poverty gaps relative to the poverty line.

\subsubsection{Construction of poverty line}

In line with recent work on poverty [2], the analysis in this study used the per capita household expenditure as a measure of poverty incidence and for determining the poverty line. The farm households were categorized into a poor and non-poor group using the two-third mean per capita expenditure [9], (World Bank, 2017) as the benchmark. Households whose mean consumption expenditure falls below the 
poverty line were regarded as being poor while those with their expenditure above the benchmark are non-poor, this is shown below:

$$
\begin{aligned}
& \text { PCE }=\frac{T C E}{H H S} \quad \text { MPCHE }=\frac{T H H E}{T N H} \\
& \text { Poverty Line }=\frac{2}{3} \text { MPCHE }
\end{aligned}
$$

Where:

PCE $=$ Per Capita Expenditure

TCE $=$ Total Consumption Expenditure

$\mathrm{HHS}=$ Household Size

$\mathrm{MPCHE}=$ Mean Per Capita Households

Expenditure

THHE $=$ Total Households Expenditure

$\mathrm{TNH}=$ Total Number of households

$\mathrm{PL}=$ Poverty Line.

\section{RESULTS AND DISCUSSION}

\subsection{Poverty Status among Crop Farmers and Fishers in the Area}

The poverty status of crop farmers and fishermen in the study area is shown in Table 1 . The poverty line estimated for this study was $A$ $21,173.66$ for crop farmers and $N 15,651.048$ for fishermen a month. Therefore, a household that

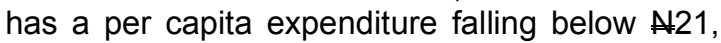
173.66 and $\mathbb{N} 15,651.048$ a month for both crop farmers and fishermen respectively were designated as poor while household that has a per capita expenditure equals or is greater than $\mathrm{N} 21,173.66$ and $\mathbf{N} 15,651.048$ for crop farmer and fishermen respectively were non-poor. It was observed that majority representing $52.5 \%$ (crop farmers) and $62.5 \%$ (fishermen) were poor, while $47.5 \%$ (crop farmers) and $37.5 \%$ (fishermen) were non-poor. This result is contrary to that of [18] who had less than $30 \%$ poverty level of farmers studied.

Poverty indicators among sampled respondents in this study were analyzed using the three indicators of poverty as highlighted in the Foster, Greer and Thorbecke (FGT) model. The indicators were the incidence of poverty, poverty depth and poverty severity. Result in Table 1 showed that, the incidence of poverty among crop farmers and fishermen were 0.525 and 0.625 respectively. This means that about $52.5 \%$ of crop farmers and $62.5 \%$ of fishermen in the study area had their per capita income less than the poverty line income. Poverty head count of $56.9 \%$ was estimated by [19] from fish vendor households in Lower Cross River Basin, Nigeria. But the result is also in line with the studies of Oladimeji et al. [20] who obtained head count of 0.53 . From this result, it can be inferred that the majority of the respondent in the study area live in poverty. The result further showed that fishermen are more vulnerable to poverty than crop farmers in the State.

The result also revealed the poverty depths of 0.342 for crop farmers and 0.309 for fishermen in the study area. This result implies that about $34.2 \%$ and $30.9 \%$ of per capita income is needed to bring poor farmers and fishermen from below poverty line up to the poverty line income. Similarly, the severity of the poverty index was 0.252 for crop farming households and 0.221 for fishing headed households in the study area. This result means that crop farmers need about $25.2 \%$ increases in per capita income to push them away from severe poverty. Likewise, the fishermen need about $10.64 \%$ increment in per capita income to escape from severe poverty.

Table 1. Summary statistics of poverty status of the crop farmers and fishers in the study area

\begin{tabular}{lllll}
\hline Poverty status & \multicolumn{2}{c}{ Farmer } & \multicolumn{2}{c}{ Fishers } \\
\cline { 2 - 5 } & Frequency & Percent & Frequency & Percent \\
\hline Poor & 21 & 52.5 & 25 & 62.5 \\
Non-poor & 19 & 47.5 & 15 & 37.5 \\
Total & 40 & 100 & 40 & 100 \\
\hline Indicators & & & & \\
\hline Incidence of poverty (P0) & 0.525 & & 0.625 & \\
Poverty depth (P1) & 0.342 & & 0.309 & \\
Poverty severity index (P2) & 0.252 & & 0.221 & \\
Poverty line & $21,173.66$ & & & \\
\hline
\end{tabular}

Source: field survey data, 2018 
Table 2. Logit model estimates of determinants of poverty status farmers

\begin{tabular}{|c|c|c|c|c|c|}
\hline Variables & Coefficients & Standard errors & Z-value & Marginal effect & Z-value \\
\hline Constant & -27.99 & 13.15 & $-2.13^{\star *}$ & & \\
\hline Gender & 2.709 & 1.751 & 1.55 & 0.672 & 1.54 \\
\hline Age & 0.279 & 0.181 & 1.55 & 0.0693 & 1.53 \\
\hline Marital Status & 2.007 & 1.161 & $1.73^{*}$ & 0.498 & $1.71^{*}$ \\
\hline Education & 0.0832 & 0.135 & 0.61 & 0.0207 & 0.62 \\
\hline Household size & -0.317 & 0.216 & -1.47 & -0.0788 & -1.47 \\
\hline Farm size & 1.178 & 0.678 & $1.74^{*}$ & 0.292 & $1.76^{*}$ \\
\hline Farm income & $-5.03 E-5$ & $4.54 \mathrm{E}-5$ & -1.11 & $-1.25 E-5$ & -1.10 \\
\hline Association & 7.425 & 3.668 & $2.02^{* *}$ & 1.843 & $2.06^{* *}$ \\
\hline Experience & -0.965 & 0.443 & $-2.18^{\star *}$ & -0.239 & $-2.18^{\star *}$ \\
\hline Log-likelihood & -14.869 & & & & \\
\hline LR chi2 (9) & $25.61^{\star \star *}$ & & & & \\
\hline Pseudo $R^{2}$ & 0.4627 & & & & \\
\hline
\end{tabular}

\subsection{The Determinant of Poverty among Crop Farmers and Fishermen in the Study Area}

The Logit model was used in estimating factors that influencing poverty among crop farmers and fishermen in the study area and the results presented in Tables 2 and 3.

\subsection{The Determinant of Poverty among Crop Farmers}

The estimated coefficients of the Logit model for crop farmers along with the standard error, zvalues and $p$-values are presented in Table 2. The Pseudo $R^{2}$ of 0.46 implies that all the explanatory variables included in the model were able to explain $46 \%$ of the variation in the poverty status of the households. The likelihood ratio statistics as indicated by the $\mathrm{X} 2$ statistic is significant at $1 \%$. This implies that all the variables included in the Logit model are jointly significant in influencing farmers' poverty status. Therefore, the socio-economic characteristics of farmers have a significant effect on their poverty status. Table 3 shows that marital status, farm size, association and farming experience are statistically significant determinants of poverty status. However, the parameter estimates of the Logit model provide only the direction of the effect of the independent variables on the dependent (response) variable: estimates do not represent the actual magnitude of change or probabilities. Thus, the marginal effects from the model, which measure the expected change in probability of a particular choice being made concerning a unit change in an independent variable, are also reported in Table 3 and were used for discussion.
The coefficient of marital status of farmers was statistically significant at $5 \%$ and had a positive effect on the poverty status in the study area. The marginal effect value of 0.498 obtained implies that, if marital status of farmer changes from single to married, the probability of the crop farming household been non-poor is $49.8 \%$. The results imply that households headed by married people are more likely to be non-poor than those headed by unmarried households. This finding is in line with that of several authors [8-10,21,22].

Farm size also had a positive and significant effect on poverty at $1 \%$ level of probability. The marginal effect value of 0.292 implies that, if farm size is increased by one unit, the probability that farming households would be non-poor is $29.2 \%$. This means that the larger the farm size, the more likely farming households would be nonpoor. Similarly, farmers' belonging to association also had a positive and significant effect on poverty status at $1 \%$ level of probability. The marginal effect value of 1.843 implies that, if a farmer belongs to the association, the probability that such farming households would be non-poor is $84.3 \%$. This means that, the more a household head belongs to the association, the more likely they would be non-poor.

On the other hand, the relationship between poverty status and farming experience of farming household head is negative and statistically significant. The marginal effect of farming experience has a negative relationship with poverty incidence among farmers in the study area. A unit increase in farming experiences will reduce poverty incidence by increasing the household per capita income of farmers by $\mathrm{N}$ 0.239 . This connotes that, as farming experience 
Table 3. Logit model estimates of determinants of poverty status of fishers

\begin{tabular}{llllll}
\hline Variables & Coefficients & Standard errors & Z-value & Marginal effect & Z-value \\
\hline Constant & 2.169 & 7.04 & 0.31 & & -0.40 \\
Gender & -0.464 & 1.16 & -0.4 & -0.0911 & -0.69 \\
Age & -0.076 & 0.116 & -0.66 & -0.0149 & -0.69 \\
Marital Status & -0.644 & 0.929 & -0.69 & -0.126 & $2.13^{* *}$ \\
Education & 0.303 & 0.161 & $1.88^{*}$ & 0.0595 & -0.48 \\
Household size & -0.098 & 0.206 & -0.48 & -0.0193 & 0.61 \\
Credit & 0.776 & 1.273 & 0.61 & 0.152 & $1.96^{*}$ \\
Farm income & $4.76 \mathrm{E}-06$ & $2.59 \mathrm{E}-06$ & $1.84^{*}$ & $9.35 \mathrm{E}-07$ & -0.93 \\
Association & -1.041 & 1.134 & -0.92 & -0.204 & 0.47 \\
Experience & 0.121 & 0.261 & 0.46 & 0.023 & \\
\hline Log-likelihood & -0.1855 & & & \\
LR chi2 (9) & $15.83^{*}$ & & \\
Pseudo R ${ }^{2}$ & 0.299 & Source: field survey, 2018. ${ }^{*}=10 \% ;^{* *}=5 \% ;{ }^{* * *}=1 \%$ &
\end{tabular}

increases, it would dwindle the prevalence of poverty among poor farming household heads. Researchers like $[18,23,24]$ obtained a similar result in other regions of the country. Also, gender, age, education, household size and farm income of the household head were not significant. This suggests that this variable might not fully explain the poverty status of a household.

\subsection{The Determinant of Poverty among Fishermen}

The estimated coefficients of the Logit model for fishermen, along with the standard error, zvalues and $p$-values are presented in Table 3 . The Pseudo $R^{2}$ of 0.299 implies that all the explanatory variables included in the model were able to explain about $30 \%$ of the variation in the poverty status of the fishermen households. The likelihood ratio statistics as indicated by the $\mathrm{x} 2$ statistic is significant at $1 \%$. This implies that all the variables included in the Logit model are jointly significant in influencing fishermen' poverty status. Therefore, the socio-economic characteristics of fishermen have a significant effect on their poverty status. Table 3 shows that education, credit experience and farm income were the only statistically significant determinants of poverty among fishermen. However, the marginal effect of the model was used for discussion.

The table showed that years of education have a positive marginal effect of 0.0595 . This shows that the probabilities of being non-poor would increase by about 6 percent for a unit increase in year of education. Several authors [19,25] also obtained years of education as the determinant of poverty among fish vendors. The result is also in line with the report of several authors $[13,25,26]$. Similarly, credit returned a coefficient of 0.776 indicating that a percent increase in this variable increases the chances of been non-poor by $78 \%$. Farm experience had a coefficient of 0.121 indicating that a unit increase in farm experience gets fishermen out of poverty $1 \%$. The result further showed that income from fishing had a positive marginal effect of $9.35 \mathrm{E}-$ 07. This indicated that the probabilities of being non-poor would increase for a unit increase in fishermen income.

\section{CONCLUSION AND RECOMMENDA- TIONS}

The present study showed that fishermen are more vulnerable to poverty than crop farmers in the State. Result also indicated that about 34.2\% and $30.9 \%$ of per capita income is needed to bring poor farmers and fishermen out of poverty. Also, crop farmers and fishermen need about $25.2 \%$ and about $10.64 \%$ increases in per capita income respectively to push them away from severe poverty. On the determinants of crop farmers, gender, age, marital status education, farm size and membership of association were all found to be positive and significant determinants, while education, credit, farm income and experience were the positive and significant determinant of poverty among fishermen in the area. The following are recommended: credit delivery mechanism which are without or with very minimal stringent conditions (such as provision of collateral) targeting the poor crop farming and fishing households should be implemented, improved crop farmers/fishermen access to technological 
information, policy actions that tend to increase educational and training opportunities for the poor should be encouraged and government should enhance the educational status of the crop farmers/fishermen through adult education which will lead to increased income.

\section{COMPETING INTERESTS}

Authors have declared that no competing interests exist.

\section{REFERENCES}

1. UNDP. Human Development Report Nigeria 2015-2016. Achieving Growth with Equity; 2017.

Available:http://hdr.undp.org/sites/default/fil es/nhdr_Nigeria_2015-2016.pdf

2. Adewunmi Ol, Adesimi B, Ezekiel OA. Non-farm activities and poverty among rural farm households in Yewa division of Ogun State, Nigeria. Journal of Social Sciences. 2011;26(3):217-224

3. Food and Agricultural Organization (FAO). FAOSTAT; 2008.

Available:www.fao.org/faostat/en

4. Olutosin A. Otekunrin, Oluwaseun A. Otekunrin, Momoh S, Ayinde IA. How far has Africa gone in achieving the zerohunger target? Evidence from Nigeria, Glob. Food Security. (Elsevier). 2019;22:112.

Available:https://doi.org/10.1016/j.gfs.2019 .08 .001

5. Food and Agricultural Organization (FAO). The state of food insecurity in the world:eradicating world hunger taking stock ten years after world food summit, Rome; 2005.

Available:www.fao.org/sof/sofi

(Retrieved on 20/4/2018)

6. Poulton C, Dorward A, Kydd J. The future of small farms: New directions for services, institutions and intermediation. World Development. 2005;38(10):14131428.

7. Etim NA, Ukoha OO, Akpan AU. Correlates of poverty among urban farming households in Uyo, Nigeria. Journal of Agriculture and Social Science. 2010;6:2933.

8. Garba A. Alleviating poverty in Northern Nigeria. Annual Convention of Zumunta Association, Minneapolis, USA; 2006.

9. Adekoya OA. Analysis of farm households poverty status in Ogun States, Nigeria.
.Asian Economic and Financial Review. 2014;4(3):325-340.

10. Edet GE, Etim NA. Factors influencing rural livelihood diversification: implications for poverty reduction. International Journal of Agriculture, Forestry and Fisheries. 2018;6(2):23-28.

11. Okunmadewa $F$, Olaniyan $S$, Yusuf $A$, Bankole O, Oyeranti B, Omonona T. Poverty and inequality among rural households in Nigeria. In O. Ogwumike (Ed.), Poverty and Inequality in Nigeria. Ibadan, Nigeria: Spectrum Books Ltd; 2010.

12. Ettah OI, Kuye OO. Socio-economic characteristics and factors affecting credit acquisition and output of rice (Oryza sativa) farmers in Yakurr Local Government Area of Cross River State, Nigeria. International Journal of Science and Research (IJSR). 2016;5(12):21202124.

13. Igbalajobi $\mathrm{O}$, Fatuase Al, Ajibefun I. Determinants of poverty incidence among rural farmers in Ondo State, Nigeria. American Journal of Rural Development. 2013;1(5):131-137.

14. Apata T, Apata O, Igbalajobi O, Awoniyi M. Determinants of rural poverty in Nige-ria: evidence from small holder farmers in south-western, Nigeria. Journal of Science and Technology Education Research. 2010;1(4):85-91.

15. Mishra PK. Padmanaban and Meenakshee Dwivedi. Modelling and forecasting of black Pepper production in India. Indian Journal of Ecology. 2017;44(4):741-745.

16. Mishra P, Padmanaban K, Dhekale BS, Tailor AK. Statistical investigation of production performance of Cumin in India. Economic Affairs. 2018;63(2):547-555.

17. National population commission. Census enumeration survey N. P. C. Abuja, Nigeria. 2011;2: 6-8.

18. Olaopa AC, Adeyemo PB, Agbonlahar R. Poverty: Meaning, measure and causes in Nigeria. Ethiopian Journal of Environmental Studies and Management. 2006;4(2):11-15.

19. Akinbode S. Profiles and determinants of poverty among urban households in SouthWest Nigeria. American Journal of Economics. 2013;3(6):322-329.

20. Oladimeji YU, Damisa MA, Abdulsalam Z, Omokore DF. A micro level analysis of poverty among artisanal rural fishery in Kwara state, Nigeria. Ethiopian Journal of 
Environmental Studies \& Management. 2014;7(4):423-433.

21. Etim NA, Patrick IV. Estimating the determinants of poverty among fishing households in Akwa Ibom State, Nigeria. Journal of Agriculture and Social Science. 2010;6(3):61-63.

22. Etuk E, Angba C, Angba A. Determinants of poverty status of fish vendor households in Lower Cross River Basin, Nigeria. Journal of Economics and Sustainable Development. 2015;6(14): 50-55.

23. Agboachom EE, Amalu M, Uzoikwe A, Ettah I, Ubi GM. Strategic policies in expanding Frontiers of food security among cassava -based farmers in Cross
River State, Nigeria. Annual Research \& Review in Biology. 2019;33(5):1-12.

24. Ubi GM, Kinglsey EN, Onabe MB, Jemide JO, Egu CJ. Organoleptic and Horticultural Characterization of Elite Cultivars of Plantain (Musa paradisiaca L.) for value addition and food security in Nigeria. Journal of Advances in Biology and Biotechnology. 2016;9(1):1-21.

25. Duniya KP, Rekwot GZ. Determinants of poverty among groundnut farming households in Jigawa State, Nigeria. Asian Journal of Agricultural Extension, Economics \& Sociology. 2015;4(3):224230.

26. The World Bank Reports; 2016.

(c) 2020 Ettah et al.; This is an Open Access article distributed under the terms of the Creative Commons Attribution License (http://creativecommons.org/licenses/by/4.0), which permits unrestricted use, distribution, and reproduction in any medium, provided the original work is properly cited.

Peer-review history:

The peer review history for this paper can be accessed here: http://www.sdiarticle4.com/review-history/54506 